\title{
Need for a clear techno-legal definition of blue gold: the river floodplains in India
}

\author{
Vikram Soni, Shashank Shekhar* and Vikrant Jain*
}

The present article highlights the need for a clear techno-legal definition of the river floodplains in India. In the context of environment protection, it reviews some of the recent judgements passed by the National Green Tribunal of India (NGT) pertaining to protection of the river floodplains. The inconsistency and differences in the legal arguments pertaining to the definition of river floodplains are highlighted. The geomorphic and hydraulic approach used for defining the floodplain of a river are discussed. It has emerged out from the discussions that the only abiding and faithful definition of the floodplain is its hydro-geomorphic character. This is manifested by sand, silt and clay and various geomorphic units associated with the depositional activity of the present day river.

Keywords: Embankment, environment, floodplain, geomorphology, hydrology, hydro-geomorphic, National Green Tribunal, techno-legal.

THE river and its floodplains are formed naturally over a time scale of hundreds to thousands of years ${ }^{1-4}$. It is very important that floodplains are correctly demarcated, as they are vast local and perennial reserves of quality water $^{5-7}$. They are a natural storage for quality water that are naturally recharged ${ }^{8,9}$. The floodplains of major rivers in India may store more than 20 times the volume of annual virgin flow in the river ${ }^{10}$. They can be used to annually supply drinking water to several cities along the river, almost free of cost. An example is the Palla well field in the Yamuna flood plain of Delhi, India which yields drinking water worth Rs 7500 million per year at the current commercial rate ${ }^{11}$.

Floodplains are also the lifeline of river systems and are critical to maintain good river health. Floodplain supports ecological diversity in a river system by: (a) Providing carbon and nutrients supply to river channel, which finally governs productivity of the entire river system; (b) Providing geomorphic (habitat) diversity in river space to support biodiversity, and more importantly (c) providing a connectivity between aquatic and terrestrial environments $^{12-14}$. Well-developed lateral connectivity between channel and floodplain is key to maintain good health of a river system. Hence, floodplains are also termed as 'blue gold', which are essential to maintain river systems and to provide fresh water to human population. It is a great pity

Vikram Soni is in the Jamia Millia Islamia University, New Delhi 110 025, India and Jawaharlal Nehru University, New Delhi 110 067, India, Shashank Shekhar is in the Department of Geology, University of Delhi, Delhi 110 007, India and Vikrant Jain is in the Discipline of Earth Sciences, IIT Gandhinagar, Gandhinagar 382 355, India.

*For correspondence. (e-mail: shashankshekhar01@gmail.com; vjain@iitgn.ac.in) that river floodplains are not being protected and are destroyed for short term gains, in spite of deteriorating health of river systems and the water contingency in India.

Floodplains have been extensively discussed in various Government of India reports, court ruling/discussions and in scientific literature. However, we are still lacking a clear and unambiguous understanding and definition of the floodplain. One of the main problems is that generally floods and their control and regulation is often confused with the floodplain, a hydro-geomorphic formation and an useful water resource.

\section{Recent judgements}

Some of the recent judgements of the National Green Tribunal of India (NGT) are based on the differing and inconsistent definitions of the floodplain. The Yamuna floodplain in Delhi has already been demarcated in the Delhi master plan and declared as a protected biodiversity zone. However, the NGT judgement ${ }^{15}$ regarding Yamuna floodplain of Delhi observed that 'Keeping in view the fact that various developments have taken place on the floodplain of River Yamuna and to a larger extent they have adversely affected the river flow, its ecology and biodiversity, we would direct that floodplain zoning should be taken with reference to the flood of once in 25 years, as against other suggested figures of more years'. The court in this case directed the concerned government agency state to demarcate the Yamuna floodplain for the flood of once in 25 years and prohibited development activity in the demarcated floodplain.

In a similar case, NGT based its judgement ${ }^{16}$ on the findings of a committee constituted for demarcation of 
floodplains of Krishna river near the city of Amravati, Andhra Pradesh. The committee summarized its findings as: 'Therefore it is evident that the flood from River Krishna does not cross the embankment/bund. Consequently, the areas beyond embankment/bund cannot be called as floodplains, ${ }^{16}$.

In case of Agra city, the court used the definition of the floodplain where the boundaries were determined by the 2010 flood in the Yamuna ${ }^{17}$. Even if we assume 2010 flood as the highest in last 25 years, it would always be appropriate to define floodplain boundaries under natural conditions without considering the effects of flood protection embankment. Further, in the NGT judgement on the Art of Living cultural festival held in the Yamuna floodplain, it was observed that 'It is undisputable that floodplains of the rivers form an essential ecological continuum of healthy rivers. These provide essential space to the rivers to spread with ease and during their flood period, flow to recharge their associated aquifers ${ }^{18}$, The arguments which formed the basis of these judgements hinted towards the fact that there was no sacrosanct definition of a floodplain.

To avoid further confusions this article therefore presents a discussion on some seminal literature which have attempted to define floodplains and ultimately aims to produce a reliable definition of a floodplain for future techno-legal use.

\section{What is floodplain of a river - the present understanding?}

Floodplain is defined on the basis of two aspects. First aspect considers only its form or elevation of its surface, which frequently gets inundated. It is based on the simple hydraulic approach which does not include material (sediment) property of the floodplain. While, the second aspect includes process-based approaches and is known as geomorphic definition ${ }^{19,20}$.

The geomorphic definition emphasizes that the floodplain surface is built by sediment of river channel due to overbank flooding on its surface. Bhowmick and Stall ${ }^{21}$ presented the geomorphic definition of the floodplain as surface built by the sediment deposition of the present day river on account of lateral migration and flooding. The point to be noted here is that Bhowmick and Stall ${ }^{21}$ emphasized on the geomorphic definition and considered all the sediments deposited by the present day river or through one high discharge event with a probability of occurrence of once in hundred years, as part of the floodplain. Nanson and Croke $^{19}$ in a highly cited work on floodplains defined it as 'the largely horizontally-bedded alluvial landform adjacent to a channel, separated from the channel by banks, and built of sediment transported by the present flow-regime'.

The floodplains of a river thus include all those areas which are underlain by the sediments deposited by the present day river at a level commensurate with the present day flow-regime.

Junk et $a .^{22}$ defined floodplains in an ecological perspective as areas which were periodically inundated by the overbank flow of a river or direct precipitation or groundwater discharge having characteristic community of biota produced as a result of morphological/anatomical, physiological and/or ethological adaptations. They recognized the positive impact of flooding on biota and also the reaction of biota to flooding.

\section{Floodplain definition, processes and its benefits}

The River Ganga (Rejuvenation, Protection and Management) Authorities Order (ref. 23), defines floodpain of river Ganga as 'such area of River Ganga or its tributaries which comes under water on either side of it due to floods corresponding to its greatest flow or with a flood of frequency once in hundred years'. However, it misses the fact that the areas which will come under water on either side of the river during flood is controlled by the flood protection embankment. Thus a wrong demarcation of a floodplain can be defined by the construction of an embankment (locally called as bandh). This is an arbitrary definition. This can be conveniently made to move the floodplain boundaries at will, i.e. closer and closer to the main river till the river is collared. This subterfuge can be used in violating the protected floodplain, by shifting the embankment. Such embankments (bandh) are for flood control measures that have nothing to do with the actual floodplains.

This is therefore arbitrary and often results in tragic events as observed in Indian cities such as the Meethi river floods in Mumbai where the water had no escape and eventually flowed over ${ }^{24}$. The more recent flood in Chennai where the water overflowed into the floodplain which was encroached by negligent buildings and, interestingly in Srinagar, where the water flowed over the bandh and then had no exit route ${ }^{24}$. This list goes on and will continue - if this is how we abridge the river and define the floodplain.

The definition of floodplain, often used by courts, government and engineers is episodic. This means that further back we go in time, the larger the floodplain becomes. Hence, this is an episodic but not an exact definition of a floodplain. Yet again flood frequency analysis is a flood indicator that is used for flood mitigation measures and is arbitrary as its frequency and extent change all the time - it does have relevance to the hydrogeological character of the floodplain. Also, channel bankfull capacity generally changes downstream along long profile. It has been observed that bankfull capacity and flood prone area in a river basin is also governed by local geomorphic controls, hence all parts of floodplain will not be inundated by a single flood event ${ }^{25}$. 
This leads to a question as to how floodplains are formed. Most of the rivers in India flow down from the mountains bringing with them an abundant load of silt and sand, flooding their courses and depositing this silt and sand on their banks. Such a floodplain building process also leads to the formation of various geomorphic units in the floodplains. Assemblage and mapping of these units provides a useful geomorphic approach to define floodplain surface along the river ${ }^{26}$, which is vital to the growth of ecological diversity. Some of these units are levee, crevasse splay (channel-fill), flood channel, floodplain sand sheet, back swamp, sand wedge, palaeochannel, ridge and swale topography, floodout, meander/chute cutoff and anabranch ${ }^{20}$. Sedimentation rate on the floodplain surface in different parts of the Ganga plains was reported to be in the range of $0.3-1.5 \mathrm{~mm} / \mathrm{year}$ (refs 1-3). Hence, floodplain development along a river channel is characterized by a time range of $10^{3}-10^{4}$ years. However, Himalayan rivers have been accumulating sediments in the Ganga river basin for millions of years, which have witnessed different episodes of climatic and tectonic changes/events. Changes in tectonic/climatic settings lead to flux variability in river channel, which further causes variability in channel processes and morphology. Such spatio-temporal variability in channel processes leads to diverse types and shapes of floodplains in different space and time. Presence of sand in floodplain (as a result of lateral channel migration process and presence of palaeochannels and crevasse splay deposits) is more important for creating groundwater-surface water interaction.

These long term depositional processes in a river basin and shifting of channel belts lead to the formation of floodplains at different times. In fact, the sediments of the entire Ganga river basin are the products of such long term river processes. However, in context of the present time, any river will always have a present day younger floodplain and disconnected older floodplains. The older floodplains are disconnected from the river channel and mostly lie at higher elevation compared to the present day floodplains ${ }^{27}$. These older floodplains rarely get inundated by river water and are characterized by lesser number of geomorphic units and widespread salt-encrusted zones. Such older floodplains are ideal sites for urban setup and infrastructural development in alluvial plain areas. Whereas, the younger floodplains associated with the current flow-regime of the river are the connected parts of surface along the river channel, which frequently get inundated by overbank flow. These are characterized by various geomorphic units, namely abandoned channels, meander scars, oxbow lakes, low vegetation cover, and high moisture content on the satellite images, which indicate connectivity with the main river channel ${ }^{27}$. These floodplains along river channels form the part of river space and hence need to be maintained with river systems $^{26}$. Furthermore, the process of demarcation of the areal extent of such floodplains should exclude the present day flood protection embankment and the river space should be the ideal space under natural conditions without any embankment.

In the above context, floodplain should be defined by its hydro-geomorphic character. In simple terms, sand, silt and clay and the various geomorphic units associated with the depositional activity of the present day river should be used for demarcation of the floodplain. The sand of a floodplain is porous and absorbs lot of water. Almost $40 \%$ of the enormous volume of sand that runs for over $1000 \mathrm{~km}$ along rivers is water ${ }^{7}$. So floodplains take in lot of water from the monsoons; from rain and during flooding. Later, they slowly release some of this water into the rivers in the non-monsoon lean period. Apart from being an organic part of the river, floodplain is by far the best natural protection from floods as it absorbs water due to its porosity.

Floodplain is also a natural subsurface storage which does not lose water from evaporation and has a natural recharge from rainfall and floods ${ }^{8,11,28,29}$. This is important because the floodplains can provide perennial local water for millions of people in cities from the annual replenishment from rain and monsoon. A scheme such as this is already providing water supply to a million people in Delhi ${ }^{5,30,11}$. A proper and scientifically managed groundwater abstraction from the floodplains will not have any significant impact on the baseflow contribution to rivers. An example for this is the scientifically designed groundwater abstraction from the Palla well field of Delhi which does not affect the river flow and rather uses monsoon flood water to replenish the aquifers.

\section{Summary and conclusion}

We conclude that the only abiding and faithful definition of a floodplain will be its hydro-geomorphic character or in simple terms, sand, silt, clay and the various geomorphic units associated with the depositional activity of the present day river. A good hydrological and geomorphic dataset and in-depth process understanding of floodplainchannel interactions are needed to define floodplains along the channels of all major river systems of India. With respect to policy development for environment protection, the practice of defining and demarcating floodplains within the embankment would be arbitrary and therefore should not form the basis of any technolegal matter. Any practical restrictions pertaining to a jacketed or incised river should only be highlighted after defining the true areal extent of the floodplain and not vice versa.

In summary, floodplains are an important part of river space. Their characteristics are the manifestations of different river processes. Floodplains are important to support and manage good river health. The wider floodplains 
are also necessary to protect cities from the kind of extreme events that accompany climate changes which have wreaked havoc in cities like Srinagar, Mumbai, Chennai and so on. The floodplain ecosystems are precious natural resources with significant tangible and nontangible economic benefits. Thus they are protected world over. A proper policy framework is needed for Indian rivers on the basis of fundamental understanding of floodplain processes (hydrological and geomorphological), which will lead to sustainable management of river systems.

1. Joshi, D. D. and Bhartiya, S. P., Geomorphic history and lithostratigraphy of a part of eastern Gangetic Plain, Uttar Pradesh. Geol. Soc. India, 1991, 37, 569-576.

2. Rajagopalan, G., Radiocarbon ages of carbonate materials from Gangetic alluvium. In Gangetic plains: Terra Incognita (ed. Singh, I. B.), Army Printing Press, Lucknow, India, 1992, pp. 45-48.

3. Sinha, R., Friend, P. F. and Switsur, V. R., Radiocarbon dating and sedimentation rates in the Holocene alluvial sediments of the northern Bihar plains, India. Geol. Mag., 1996, 133(1), 85-90.

4. Soni, V., Shekhar, S. and Singh, D., Environmental flow for the Yamuna River in Delhi as an example of monsoon rivers in India. Curr. Sci., 2014, 106(4), 558-564.

5. Rao, S. V. N., Kumar, S., Shekhar, S., Sinha, S. K. and Manju, S., Optimal pumping from skimming wells from the Yamuna River flood plain in north India. Hydrogeol. J., 2007, 15(6), 1157-1167.

6. Shekhar, S. and Prasad, R. K., The groundwater in the Yamuna flood plain of Delhi (India) and the management options. Hydrogeol. J., 2009, 17(7), 1557-1560.

7. Shekhar, S., Mao, R. S. and Imchen, E. B., Groundwater management options in North district of Delhi, India: a groundwater surplus region in over-exploited aquifers. J. Hydrol: Reg. Stud., 2015, 4, 212-226; http://dx.doi.org/10.1016/j.ejrh.2015.03.003

8. Shekhar, S., Environmental flows and river rejuvenation. Geol. Soc. India, 2016, 88(6), 813-814.

9. Sarkar, A., Shekhar, S. and Rai, S. P., Assessment of the spatial and temporal hydrochemical facies variation in the flood plains of North-West Delhi using integrated approach. Environ. Earth Sci., 2017, 76(19), 665; https://doi.org/10.1007/s12665-017-7019-5

10. Soni, V., Drought in India: conserving forests, effective use of floodplains can quell water shortage, interview to firstpost, 2017; http://www.firstpost.com/india/drought-in-india-conserving-forestseffective-use-of-floodplains-can-quell-water-shortage-says-profvikram-soni-3448708.html (accessed on 1 March 2018).

11. Soni, V., Shekhar, S., Rao, S. V., Kumar, S. and Singh, D., A new solution for city water: quality drinking water from the river floodplains. Curr. Sci., 2018, 114(3), 452-461.

12. Richards, K., Brasington, J. and Hughes, F., Geomorphic dynamics of floodplains: ecological implications and a potential modelling strategy. Freshwater Biol., 2002, 47, 559-579.

13. Gurnell, A. M. and Petts, G. E., Island-dominated landscapes of large floodplain rivers, a European perspective. Freshwater Biol., 2002, 47, 581-600.
14. Thoms, M. C., Floodplain-river ecosystems: lateral connections and the implications of human interference. Geomorphology, 2003, 56, 335-349.

15. NGT, Manoj Mishra vs Union of India, Original Application No. 6 of 2012, order pronounced on 13-01-2015, 2015; ielrc.org/content/ e1504.pdf (cited 13 December 2017).

16. NGT, Pandalaneni Srimannarayan and Anr. vs State of Andhra Pradesh and Ors., Original Application No. 171 of 2015, order pronounced on 17 November 2017.

17. NGT, Uma Shankar Patwa and Anr. vs Union of India and Ors., Original Application No. 145 of 2015, order dated 23 January 2017; source: http://www.indiaenvironmentportal.org.in (cited 13 December 2017).

18. NGT, Manoj Mishra \& Anr. Vs. Union of India \& Ors., Original Application No. 65 of 2016, (order pronounced on 7 December 2017).

19. Nanson, G. C. and Croke, J. C., A genetic classification of floodplains. Geomorphology, 1992, 4(6), 459-486.

20. Brierley, G. J. and Fryirs, K. A., Geomorphology and river management: applications of the River Styles Framework. Blackwell, Oxford, 2005, p. 398.

21. Bhowmik, N. G. and Stall, J. B., Hydraulic geometry and carrying capacity of floodplains, University of Illinois Water Resources Research Centre, 1979, Research Report No. 145.

22. Junk, W. J., Bayley, P. B. and Sparks, R. E., The flood pulse concept in River-Flood plain systems. In Proceedings of the International large River. Symposium (ed. Dodge, D. P.), Can. Spec. Publ. Fish. Aquat. Sci., 1989, vol. 106, pp. 110-127, https://www. nrem.iastate.edu/class/assets/aec1518/.../Junk_et_al._1989.pdf (accessed on 7 April 2018).

23. GOI, The Gazette of India (GOI): Extraordinary (PART II-SEC. 3(ii)], The River Ganga (Rejuvenation, Protection and Management) Authorities Order, 2016.

24. Soni, V., Naturally: Tread Softly on the Planet, Harper Collins India, 2015.

25. Jain, V. and Sinha, R., Geomorphological manifestation of the flood hazard. Geocarto Int., 2003, 18(4), 51-60.

26. GRBMP, Ganga River Basin Management Plan (GRBEMP) Reports 580 (http://nmcg.nic.in/Grbmpreports.aspx; 2011, Report 021_GBP_IIT_FGM_DAT_02_Ver1_Dec 2011.

27. Sinha, R., Jain, V., PrasadBabu, G. and Ghosh, S., Geomorphic characterization and diversity of the fluvial systems of the Gangetic Plains. Geomorphology, 2005, 70, 207-225.

28. Soni, V., Gosain, A. K., Datta, P. S. and Singh, D., A new scheme for large-scale natural water storage in the floodplains: the Delhi Yamuna floodplains as a case study. Curr. Sci., 2009, 96(10), $1338-1342$.

29. Soni, V. and Singh, D., Floodplains: self-recharging and selfsustaining aquifers for city water. Curr. Sci., 2013, 104(4), 420422 .

30. Shekhar, S. and Rao, S. V. N., Groundwater management in Palla well field of Delhi using numerical modeling technique - a case study. Bhu-Jal News, 2010, 25(3\&4), p. 46.

Received 24 March 2019; revised accepted 8 August 2019

doi: $10.18520 / \mathrm{cs} / \mathrm{v} 117 / \mathrm{i} 12 / 1958-1961$ 